\title{
Organizational Commitment Viewed from Manager's Transformational Leadership Style
}

Fatwa Tentama

Fakultas Psikologi Universitas Ahmad Dahlan Jl. Kapas No 9 , Semaki, Yogyakarta, 55166

Fatwa_ten10@yahoo.com

\begin{abstract}
The research aims at testing empirically the influence of manager's transformational leadership style on organizational commitment. The proposed hypthesis is positive relationship between manager's transformational leadership style and organizational commitment.The subjects of the research are 40 employees of Batik Company "Nyonya Indo". The subjects used in the research should meet the requirements, i.e.: 1). Men and women, 2). Permanent employee, 3). Have been working at least for a year. Transformational leadership style and organizational commitment scales were used to collect the data. The method of data analysis used is product moment correlation of Pearson through SPSS program of 17.00 for windows version. The result shows that there is significant positive correlation between manager's transformational leadership style and organizational commitment. This is depicted in $r=0,297$ and $p<0,05$. It means that the higher the transformational leadership style is applied, the higher the organizational commitment and vice versa. The number of the influence of manager's transformational leadership style on organizational commitmentis 7,841 $\%$.
\end{abstract}

Keywords: organizational commitment, transformational leadership style,

\section{INTRODUCTION}

Human resources are the most valuable and vital assets owned by a company that their use and maintenance in the company is the key success to reach its goal. A company thinks that an employee as one of human resources should have commitment to the company. Great commitment to the company will bring to the profitable condition, since the employees will work more effective and participate to sustain the company from the bad condition. The commitment to organization will be energy supply for the organization in the times of crisis in which it needs the employees badly (Milner, 1993). Besides, the employees also help the company to achieve the target to keep the quality and productivity, because the committed employees will do their best for the company (Dessler, 1993).

Steers and Porter (1990) state that the employees with low commitment will obstruct the achievement of organization's goals because such employees will tend to be concerned with their own interests rather than those of the company. Mathieu and Zajac (1990) add that the employees with high commitment will bring positive impact for the company, such as the increasing productivity, quality of work, job satisfaction, and the decreasing delay attendance to the office and delay in receipt of turnover. The committed employees will possibly perform 
based on the company's values and norms. Milner (1993) adds that the high committed employees will reduce the level of staff turnover and absenteeism and give satisfaction to the employees. This will bring effect for a company to make efforts to create the stability of labor condition.

In fact, in the company where the research is conducted, there is employee's low commitment, i.e.: (1) In 2008, there were 7 staff turnover and in 2009 it increased to 9 turnover; (2) The level of staff absenteeism during 20092011 wasslightly high and the employees were often seen ditching work; (3) There were a lot of work delays; the employees came just for giving signature of presence and doing casual work; (4) There are senses of disappointment and dissatisfaction with what the company provided that there was the desire of employees to leave the company. The low level of staff's commitment will hinder the achievement of the company's goals. There are a lof factors which influence the staff's commitment; one of them is the manager who does not care and know the staff's needs and demands.

From the interviews with some staffs, it is found that the staffs blamed the way the manager gave policies without understanding the staff's needs and that he was not able to treat the staffs well that the staff's commitment was getting decreased. To be able to achieve the goals, the managers or corporate leaders are required to be able to provide good leadership that will it be possible to affect the commitment of employees so that employees are willing to work on a high degree of effort for the benefit of the company. When the employees can feel the action patterns of good leadership and cozy with the manager, the company will be getting more positive because of the support/full participation of employees.

There are several factors that affect the Organizational commitment to one of them is the transformational leadership style. Leadership style, according to Davis and John (1985), is the overall leader's act patterns as perceived by his/ her staffs. The leadership style in a company will bring a constructive change through the improvement of future vision that the appropriate style will also support the staff's adaptation process well. The staffs under good leadership will support themselves to be always oriented toward the company and willingly to work hard, to stand being the member of the company and to be able to work effectively. Therefore, the manager's leadership style is able to affect the staffs, the company's atmosphere and environment. The way a manager affects the staffs until they do what he/she orders will be much depended on the leadership style the manager uses. However, there is no effective leadership style which prevails generally in any situation(Gibson dkk., 1982).

Leadership is the old topic and there have been a lot of theories developed to discuss it. One of the most recent theories of leadership which is fascinating to be observed is transactional and transformational leadership. Bass (1985) has developed the theory of leadership based on 2 (two) main concepts, namely transactional and transformational leadership. In this era, the expected leadership style is transformational one since the style possibly motivates the followers by making the staffs more realize the importance of the results of a work and encourage them to be more concerned with the organization than with their own interests.

In comparison, transformational leadership shows better results than transactional one does. Bass and Avolio (1990) state that the application of transformational leadership style is able to bring more fundamental changes, such as the development of values, goals and staffs' needs, and the changes will give impact to the staff's efforts. Astaff who is fulfilled highly with his needs will be more encouraged to make more efforts 
in achieving more optimal work. Besides, Bass (1985) states that transformational leadershipcorrelates positively and significantly with the amount of extra efforts made by the staff. Bycio, et.al (1995) states thattransformational leadership encourages the staff work harder and better.

Empirially, transformational leadership style is proved to be effective used in collective/group tasks, as opposed to transactional leadership which is effective in the execution of individual tasks. According to Baron (in Sunarsih, 2001), leadership with the capacity of the most effective changes orientation to the future is transformational leadership. Leaders who apply transformational leadership style move employees with vision, motivate, and stimulate them to be creative and they are sensitive to the wishes of employees. Thus, transformational leadership is an approach intended to influence employees by not only using logical but also emotional reasons. This argument is supported by a number of researches, such as like Dumdum, Lowe, and Avolio (2002).

Organizational commitment is defined as a situation in which an employee is in favor of a particular organization and its goals, and intends to maintain membership in the organization / company (Blau dan Boal, 1987).Yuwono (2005) explains that organizational commitment is an individual interest in the goals, values , and targets of the organization.

Allen dan Meyer (1990) also state that commitment can be formulated in three aspects: first, affective commitment is an emotional attachment between an employee with the company and employee engagement in an organization; second, continuous commitment is when an employee continues to work because he/she will loss or be sacrificed a lot by leaving the company; third, normative commitment is a feeling of obligation to remain to be or to stay in the company.
According to Burns (1978), transformational leaders are ones who recognize the need and demand for their staffs, look for their potential motives, and convince them for the higher needs by treating them as a whole person. Bass (in Yukl, 2009) states that transformational leadership style is the style of leadership that can motivate their followers in three ways: a). to make them more aware of the importance of the results of a job, b). to encourage them to be more concerned with the organization or team rather than self-interest. and c). to activate their needs at a higher rate. The transformational leadership style is formulated in four aspects, according to Bass (1985, 1990), namely charisma, inspirational motivation, intellectual stimulation, and individual consideration.

In the end, the transformational leadership style is able to win the loyalty, commitment, enthusiasm of employees/staffs ((Danim, 2004). Without supervision, highly committed employees will work as effectively and efficiently as possible. According to Bass (1998) the employee's commitment is higher when the leaders are more transformational.

The followers of transformational leaders demonstrate a higher level of commitment to the mission/goals of the organization, willingness to work hard, higher trust towards leaders and higher levels of cohesion (Avolio, 1999). House (1997) notes that at least there are more than one hundred empirical testing which indicate that transformational leadership is described as having a positive effect on employee's satisfaction and commitment. This is supported by a research conducted by Pursantol \& Adisubroto (2001) which shows that there is a positive relationship between transformational leadership style and a commitment to the organization. It means that transformational leadership can improve employee commitment to the organization/ company. 
The above description contains a subject matter that there may be assumption of the relationship between transformational leadership style and employee commitment to the organization. This means it is possible that transformational leadership style affects employee commitment to the organization. The hypothesis of this study is that there is a positive relationship between transformational leadership style and organizational commitment in the Batik company “Nyonya Indo”, Bantul.

\section{METHOD}

The subjects of the research are 40 employees of Batik Company "Nyonya Indo". The subjects used in the research should meet the requirements, i.e.: 1). Men and women, 2). Permanent employee, 3). Have been working at least for a year.

The data are gained using method of collecting data; scale. The scales used in this research are the scale of transformational leadership style and organizational commitment. Transformational leadership style was measured by the scale of the style which refers to the aspects of transformational leadership style based on Bass (1985, 1990), such as charisma, inspirational motivation, intellectual stimulation, and individual consideration. Organizational commitment was measured with a organizational commitment scale which refers to those aspects of the organizational commitment by Allen and Meyer (1990), which are affective commitment, continuance commitment, and normative commitment.

Tryout conducted at the Batik company "Nyonya Indo". The number of subjects that are tested as many as 45 subjects. Scales are distributed as much as 45 scales and are eligible to be analyzed by 44 scales, while the one scale disqualified because the subject did not complete the answer statements. Items that are selected at each scale were used in the research. Result of test on 40 items of transformational leadership style scale was analyzed for validity and reliability. Validity coefficient moves from 0,251to 0,575 and the reliability coefficient (á) of 0,790 , while the result of test on 36 items of organizational commitment scale validity coefficient moves from 0.253 to 0.627 and the reliability coefficient (á) of 0.842 . Data analysis was done using program of Statistical Product and Service Solution (SPSS) 17.0 for windows with correlation statistical technique of product moment by Pearson.

\section{RESULTS AND DISCUSSION}

The hypothesis which says that there is positive relationship between manager's transformational leadership style and employee's organizational commitment in Batik company "Nyonya Indo" is presented by coefficient correlation of 0.297 . This shows that there is positive relationship between manager's transformational leadership style and organizational committment. Chance of error (p) is 0.031 ( $p<0.05$ ), which means that the correlation between transformational leadership style and organizational commitment is significant. In other words, it can be said that there is significant positive correlation between manager's transformational leadership style and employee's organizational commitment in Batik company "Nyonya Indo". The higher the transformational leadership style which runs, the higher the organizational commitment of employees. On the contrary, the lower the transformational leadership style that is run by the leader, the lower the organizational commitment of the employees. It can be concluded that the hypothesis proposed in this study is accepted.

The findings in this study are also support previous study, that the transformational leadership style is able to win the commitment of employees (Danim, 2004). In relation to that, 
Bass (1998) says that employee's commitment will be higher if the leaders are more transformational. This is in line with Bass (Howell and Avolio, 1993) that transformational leadership can make employees perform more than expected, as a result of the influence of leadership. Hard working, intrinsic motivation in the work and understanding of the mission of the employees become part of their commitment to leadership. Furthermore, transformational leaders can understand and be sensitive to the problems and the needs of each employee. The employees feel close and get special attention so that they are willing to sacrifice and work whole heartedly in order to be independent and more advanced (Anoraga, 2001).

As previously stated by House (1977), at least there are more than one hundred empirical testing which indicate that transformational leadership is described as having a positive effect on employee's satisfaction and commitment. This is supported by a research conducted by Pursantol \& Adisubroto (Jurnal Sosiohumanika, 2001) which shows that there is a positive relationship between transformational leadership style and a commitment to the organization.

The researcher also has conducted an analysis to determine how many of the variables affecting the transformational leadership style on the organizational commitment of employees in the Batik company, $\mathrm{SE}=7.841 \%$. It means that the influence of transformational leadership styles on the organizational commitment of employees is $7,841 \%$. Nevertheless, these variables have showed that the problem of transformational leadership style is an important factor to get attention because it has a positive and significant relationship with organizational commitment as an attempt to deal with organizational issues, especially regarding with the commitment of the employees in the company.

Transformational leadership style is not the sole variable that affects the commitment to organization among employees in that other influencing variables are numerous. Therefore, other factors with potential impact on commitment to organization among employees need also to be considered, such as personal (age, sex, education, and capacity), job, organization and working experience (Mathieu \& Zajac, 1990), as well as personal (expectation of success, need for job, psychological contract), organizational and non-organizational factors (Northcraft \& Neale, 1990).

\section{CONCLUSION}

Based on the results of the data analysis and discussion in this study, it can be concluded that there is a significant positive relationship between transformational leadership style and organizational commitmentin Batik company "Nyonya Indo". The theoretical benefits of research's results is enriching the culture of science research industrial and organizational psychology. Especially the study of the transformational leadership style on the organizational commitment. The influence of transformational leadership styles on the organizational commitment of employees is $7,841 \%$. The rest of $92,16 \%$ derived from other variables so for the next researcher who would like to develop this research so that it's become more broadly should be examined by looking at other variables that affect the organizational committmentsuch as personal (age, sex, education, and capacity), job, organization and working experience, as well as personal (expectation of success, need for job, psychological contract), organizational and nonorganizational factors.

\section{REFERENCES}

Allen, N.J. \& Meyer, J.P. (1990). The measurement and antencedent of affective, continuence and normative comitment to the organozational. Journal Occupational Psychology. Vol. 63, 1-18. 
Anoraga, P. (2001). Psychology leadership. Jakarta: Rineka Cipta

Avolio, B. (1999). Full leadership development: Building the vital forces in organization. Thousand Oaks: Sage Publications.

Bass B.M. (1985). Leadership and performance beyond expectations. $1^{\text {st }} e d$. New York: The Free Press, A Division of Mecmillan Inc.

Bass B.M. (1990). Bass \& Stogdill's handbook of leadership: Theory, research and managerial applications. $3^{\text {rd }} \mathrm{ed}$. New York: The Free Press, ADivision of Mecmillan Inc.

Bass B. M. (1998). Transformational leadership industrial, militery and education impact. New Jersey: Laurence Eribaum Inc.

Bass, B. M., \& Avolio, B. J. (1990). The implications of transactional and transformasional leadership for individual, team and organizational development.4, 231-272.

Blau, G. J. Boal K.R. (1987). Conceptualizing how job invovement and organizational commitment affect turnover and abstenteeism. Academy of Management Review.

Burns, J. M. (1978). Leadership. New York : Herper \& Row.

Bycio., Peter., Hacet, R. D., \& Allen, J. S. (1995). Furter assesment of Bass's (1995). furter assesment of Bass's (1985) Coceptualization of transformasional and transactional leadership. Journal of Applied Psychology. No. 80 (4), 468-478.
Danim, S. (2004). Motivation leadership and effectiveness group. Rineka Cipta.

Davis, K. \& John W. N.. (1985). Human behaviour at work: Organizational behaviour. New York: Mc. Graw-Hill Inc.

Dessler, G. (1993). Winning commitment: How to build and keep a competitive workforce. Singapure: Mc. GrawHall Inc.

Gibson, J. I., Ivancevich, J. M., Donnelly, J.H. (1982). Organizations, Behavior, Structure, Processes. $4^{\text {th }}$ ed. Richard D. Irwin Inc.

House, R. J. (1997). A 1976 theory of charismatic leadership. In JGHLL Larson (Ed.), Leadership: The cutting edge (pp. 189-207). Carbondale, Il: Southern Illinois University Press.

Howell, J.M \& Avolio, B.J. (1993). Tranformational Leadership, Transactional Leadership, Locus of Control, and Support for Inovation, Key Predictor ConsolidatedBussiness-Unit Performance. Journal of Applied Psychology, vol 78, no. 6, 891-902.

Mathieu, J.E. \& Zajac, D.M. (1990). A review and meta analysis of the antecedents, correlates and consecuencess of organizational commitment. Psychology Bulletin, 10, 171-173.

Milner, J.B. (1993). Industri-organizational psychology. Singapore: Mc Graw Hill Book Co.

Pursantol \& Adisubroto. (2001). Relationship between transformational and transactional leadership style with organizational commitment. Jurnal 
Sosiohumanika. 74(l).

Steers, R.M. \& Porter, L.W. (1990).

Motivational and work behavior:

New York: McGraw-Hill.

Yukl, G. (2009). Leadership in organizations.

$5^{\text {th }}$ ed.Translation: Budi Supriyanto.

Jakarta: PT Indeks. 
